\title{
Confucius or Goethe? Cameroon's External Relations with China and Germany and Their Impact on Higher Education Aspirations of Young Cameroonians
}

\begin{abstract}
The main interest of this article is directed to the question, in how far the foreign cultural and educational relations, which Cameroon has with China and Germany, affect the international mobility of Cameroonian graduates. This paper is based on results of an empirical study in Cameroon which examined the German as well as the Chinese mechanisms within their respective cultural and educational institutions for international mobility in higher education based in Cameroon. Furthermore, the motives of Cameroonian students for their choice of destination are elaborated upon.
\end{abstract}

Keywords: mobility in Higher Education, foreign cultural and educational policies, Cameroon, China, Germany

\section{Zusammenfassung}

In diesem Beitrag wird der Frage nachgegangen, inwieweit die auswärtige Kultur- und Bildungspolitik Kameruns mit der Volksrepublik China sowie mit der Bundesrepublik Deutschland Auswirkungen auf die internationale Mobilität kamerunischer Studierender im Hochschulbereich haben kann. Dieser Beitrag basiert auf einer empirischen Studie in Kamerun. Verglichen wurden in dieser die Mechanismen der Hochschulmobilität, die seitens der deutschen sowie der chinesischen auswärtigen Kultur- und Bildungspolitik in Kamerun implementiert werden. Ferner wurden kamerunische Studierende hinsichtlich ihrer Motive, ein Studium in Deutschland respektive China durchzuführen, befragt.

Schlüsselworte: Hochschulmobilität, auswärtige Kultur-und Bildungspolitik, Kamerun, China, Deutschland

\section{Introduction}

"Ň̆ hăo", or "Guten Tag"? - today large numbers of Cameroonian graduates decide to learn Chinese or German as a foreign language; these are mandatory assets for their international mobility in higher education (cp. Tab. 1). In comparing Germany's and China's foreign cultural and educational policies, striking differences occur: whilst the Peoples Republic of China
(PRC) offers various scholarships to Cameroonian students starting from undergraduate level, the Federal Republic of Germany has nothing similar to offer. Reasons for this are seen in the strategies implemented by the respective governments, which appear to be clear cut by the PRC, for instance, concerning the criteria for a study visa and the number of available study visas. This is less well defined in German foreign policy. Consequently, the Chinese Government provides flexible mechanisms for international mobility in higher education from undergraduate level onwards, whereas similar arrangements are clearly not provided by the German government.

\section{Conceptual framework of cultural and educational policies}

This contribution mainly concentrates on cultural and educational policies which are generally considered as the "third pillar" of foreign policies, aside from political and economic policies (Schneider, Kaitinnis, 2016, p. 9 f.). Cooperation on education can be regarded as one form of external relations exercised by intermediate parastatal organisations such as the German Goethe Institute (GI) and the German Academic Exchange Service (Deutscher Akademischer Austausch Dienst, DAAD) which is the national German institution for international academic cooperation), or the Chinese Confucius Institute (CI) and its headquarters Hanban (Confucius Institute Headquarters, Hanban, 2014). The "third pillar's" influence abroad is considered to be sustaining, visible and as an immediate instrument, since its integration in the host countries reaches the populations directly and individually (Auswärtiges Amt, 2015). Overall, foreign cultural and political institutions are meant to enable direct dialogue, sustaining relations, peacebuilding and prevention of conflicts, as well as collaboration with partner institutions, the local society, and intercultural and international exchange. Consequently, interventions consisting of providing education opportunities in foreign countries are classified as 'soft power' strategies (cp. Adick, 2016; King, 2013), which, according to Joseph Nye (1990, p. 154 ff.) stands for non-military forms of international policy implementation based on technological advancements, education and economic power. Soft power is, therefore, the capacity to 


\begin{tabular}{|l|c|c|}
\hline & Chinese & German \\
\hline $\begin{array}{l}\text { (Under)graduate scholarships provided by the foreign go- } \\
\text { vernment per year }\end{array}$ & 130 & 0 (undergraduate) \\
\hline $\begin{array}{l}\text { Foreign language learners in the Cameroonian compulsory } \\
\text { school system (applies for the year 2015) }\end{array}$ & ca. 2.000 & ca. 220.000 \\
\hline Directly managed Cameroonian middle-schools (2017) & 7 & 5 \\
\hline $\begin{array}{l}\text { Language Students at the foreign cultural and political institutions } \\
\text { (Goethe Institute or Confucius Institute) }\end{array}$ & ca. 8.000 & ca. 2.800 \\
\hline
\end{tabular}

Table 1: Comparing the spread of Chinese and German language learners in Cameroon;

Source: Confucius Institute, Yaoundé ; Auswärtiges Amt 2015; Ndukong 2017.

do or change something and to let this appear as legitimate from the perspective of others (ibid., p. $167 \mathrm{ff}$.). In the following paragraphs, the local effects of foreign education and cultural policies within the context of international mobility in higher education will be discussed with the example of Cameroonian graduates.

\section{Higher education mobility as a means for cultural and educational foreign policy}

One means of higher education mobility are scholarships given to qualified students. Next to ca. 100 language-related undergraduate and postgraduate scholarships yearly awarded by the CI, the Chinese government awards about 30 undergraduate and graduate study grants to highly qualified Cameroonian students. Scholarships are part of Sino-Cameroonian cultural and educational relations. In the academic year 2017/18 the Chinese government, for instance, awarded about 132 scholarships to top Cameroonian students (cp. Tab. 1); the grants were related to the following courses: mining, industrial fishing, medicine, accounting, finance, management and logistics, renewable energies, environmental sciences, network and telecommunication, agriculture, computer sciences, information technology, electricity, international relations, international law, Chinese language. The scholarship holders receive a monthly stipend of about 252.000 CFA (app. 380€) plus the coverage of the university fees.

The CI scholarships are awarded to Chinese language students who have passed the necessary minimum points in the Chinese language proficiency test HSK (Hànyǔ Shǔping Kăoshi tests: written: HSK and oral: HSKK), which is comparable to the British TOEFL examination. The various scholarship programmes depend on the level of language competency; as for instance, for lower HSK-levels there are four-week scholarships or a one-semester study with home-stay experience in a Chinese family and studies in traditional Chinese Medicine and Taiji culture. Higher HSK-levels qualify for scholarships for Master's or Bachelor's Degrees in Teaching Chinese as a foreign language. Compared to the German language courses offered at the GI, the course fees per session (ca. 12-13 weeks) at the CI are quite moderate of 40.000 CFA (app. $61 €$ ), whereas they are threefold at the GI amounting to 135,000 CFA (app. $206 €$ ).
In contrast to the Chinese policy the criteria for eligibility for a German study visa consist of the Cameroonian baccalaureate, German language competencies of at least B1 level of the European reference framework of language learning, as well as financial resources, either in the form of a scholarship or held in a bank account (Deutsche Botschaft Jaunde, 2018). Currently, the German government does not offer any direct higher education mobility mechanism in form of a structured undergraduate scholarship programme, which enables direct entry into German universities. Nonetheless, Germany remains a highly desired destination for Cameroonian students. For instance, in 2015, Cameroonian students were the 9th largest group of international students in German universities, counting 6.672 students. Their number has been constantly rising, in the year 2005 counting 5.245 and in 2010 reaching 5.383 Cameroonian students (Burkhart et al., 2016, p. 17). As the understanding of the German language is mandatory in order to apply for a study visa there are annually high numbers of Cameroonians German language students: about 1.900 at five universities, 4.000 at language training centres and about 2.800 at the Goethe Institute, which remains Germany's leading actor in promoting the German language abroad (Auswärtiges Amt, 2015, p. 11). Both the CI and the GI referred to their directly managed schools. While the GI coordinates the PASCH-initiative (Partnerschulnetzwerk) operated in five Cameroonian-run middle schools (college and lycee) which are part of the PASCH network, the CI coordinates Chinese expatriates who are teaching Chinese lessons at seven private Cameroonian schools.

\section{Research design}

In May 2018, the author undertook a small study in Yaoundé to examine the motivations of Cameroonian graduates aiming to study in Germany or in China. For this purpose, 67 German language learners at the Goethe Institute and 71 Chinese language learners at the Confucius Institute were interviewed. Both groups answered equal questions on standardised questionnaires written in French, which were slightly adapted to the specific learning institution the contacted students attended, as well as to the circumstances related to their desire to study abroad. For instance, the students contacted at the CI were all planning to apply for Chinese language learning related 
scholarships. Notwithstanding, these students explained, once they started studying in China with the support of a CI scholarship, they would try to apply for a second scholarship awarded by the Chinese government, to prolong their stay and study a different course. Hence, their answers given in the questionnaire need to be read and understood against this background. Also, the financial situation of German language learners was different. As there are no undergraduate scholarships for Cameroonians to study in Germany, the students were more or less forced to self-support their stay in Germany and this fact had also been explicitly addressed in the questionnaire issued to them.

Students of different learning grades were contacted in both institutions in order to have a heterogeneous sample. Furthermore, they were asked to give information on their socioeconomic background, aspects of their academic aspirations and ambitions in life. The questionnaires were evaluated according to quantitative social research methods. Descriptive analyses were conducted to compare the different motives stated by Cameroonian students in light of their chosen destination. Apart from the student's survey, expert interviews with employees of the DAAD, the CI and the GI were conducted.

\section{Motives for higher education in China or Germany}

The groups of language learning students show differences, particularly in terms of age: While the eldest German language learner is 26 years old, the eldest Chinese language learners are almost 10 years older (cf. Tab. 2). Reasons for this can be related to the different visa policies. The Chinese scholarship programmes express vantages in promoting the language acquisition of university graduates, professionals or civil servants and include these applicants up to the age of 35, provided that they declare to return to their company after their study stay in China.

The Chinese demand of competent Chinese speaking Cameroonians has already been notified by Cameroonian stu- dents, who have claimed they wanted to learn Chinese, since the Sino-Cameroonian political and trade relationship is based on a solid political foundation and subsequent job opportunities appear to be plentiful (cf. Tab. 3). Moreover, they positively value the flexible visa policy as well as the high academic standards offered at Chinese universities.

Such pull-factors stressed by the German language learners differ from the ones mentioned by the Chinese language learners (cf. Tab. 3). The interviewed students plan to study in Germany because they want to meet high academic standards there $(31 \%)$ and attain an internationally accredited university degree (12\%). Moreover, the question of paying university fees is highlighted here, too, and the fact that no such fees are demanded in German higher education makes Germany appear attractive, since these study aspirants are not granted scholarships which cover such expenses. Furthermore, the students hope to live in a country with a modern lifestyle and benefit from better job prospects after graduating from university.

The high academic and technological standard met in Germany corresponds strongly with the choice of the interviewees' attempted study subject (cf. Tab. 4). German language learners plan to study subjects in engineering (22\%) or information technology $(25 \%)$ or health and medical science (14\%). Other subjects are e.g. social sciences, fashion design or International Relations, linguistics/translation. The picture is different in respect to the Chinese language learners. More than half of them plan to professionalise their Chinese language competences at a Chinese university (56\%), or to study economics (14\%). Only few decide to study engineering $(4 \%)$, health and medical sciences $(6 \%)$ or information technology (6\%). These results, however, have to be read cautiously, as already explained before, Cameroonian students studying in China may have the opportunity to apply for a second scholarship for another study course other than Chinese language and culture.

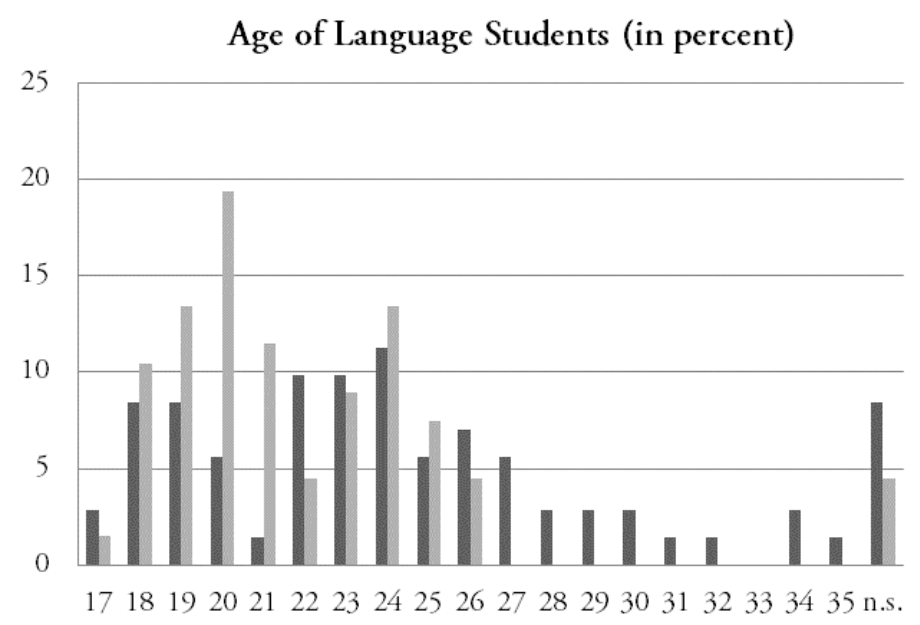

Age of Chinese language students $(\mathrm{N}=71) \quad$ Age of German language students $(\mathrm{N}=67)$ 


\begin{tabular}{|c|l|c|c|l|c|}
\hline & $\begin{array}{l}\text { Motive of Confucius Institute } \\
\text { Students }(\mathbf{N}=\mathbf{7 1})\end{array}$ & numbers in \% & $\begin{array}{l}\text { Motives of Goethe Institute } \\
\text { Students (N = 67) }\end{array}$ & numbers in \% \\
\hline 1. & Learning a foreign language & 26 & 1. & High academic standards & 31 \\
\hline 2. & High academic standards & 20 & 2. & Internationally accredited degrees & 12 \\
\hline 3. & Easy to migrate to & 14 & 3. & No school fees & 9 \\
\hline 4. & $\begin{array}{l}\text { Better working conditions } \\
\text { after university studies }\end{array}$ & 12 & 4. & Modern technology/life & 9 \\
\hline 5. & Political and trade relations & 9 & 5. & $\begin{array}{l}\text { Better working conditions } \\
\text { after university studies }\end{array}$ & 8 \\
\hline
\end{tabular}

Table 3: Top-5-Motives for higher education mobility in percent; Source: own research data.

\section{Choice of study subject in percent}

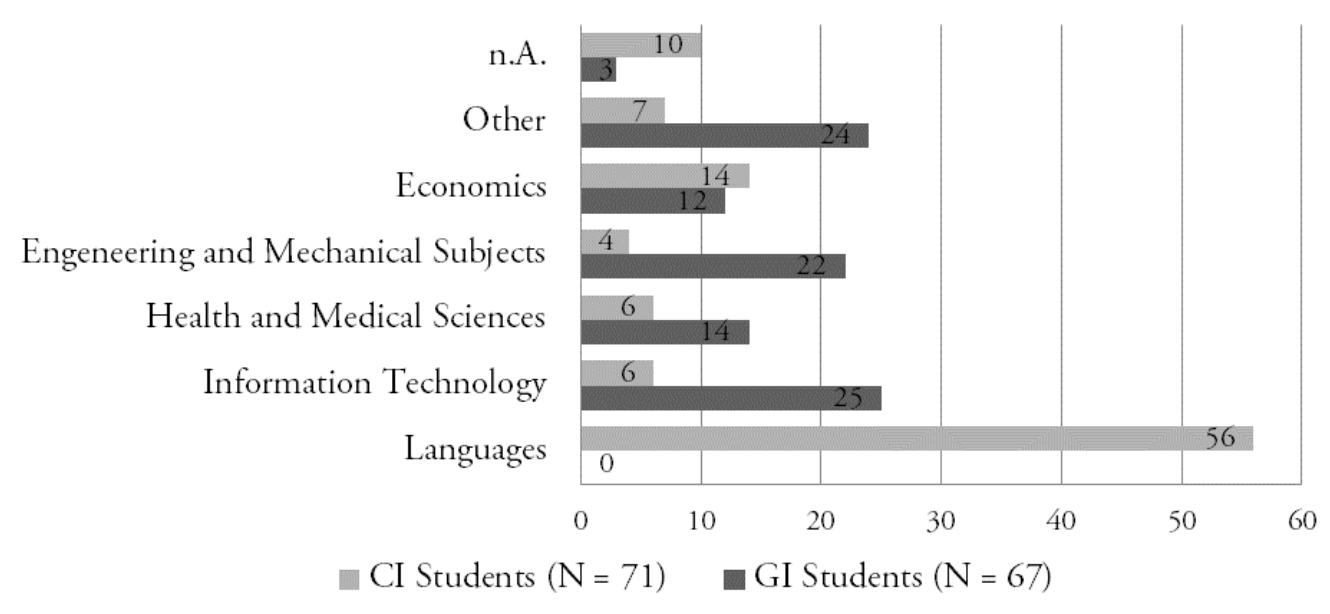

Table 4: Choice of sudy subject in percent; Source: own research data;

N. A.: no answer given.

\section{Discussion}

The results of the study point out the differences between the currently implemented German and Chinese foreign cultural and educational policies. Chinese language learners straightforwardly argue that they see clear chances in studying in China, since scholarships are provided directly from undergraduate level - this, however, is not the case for German visa aspirants. The scientific literature discusses traditional donor countries as shying to enable young academics to study abroad as from undergraduate stage, because they fear they might not plan to return to their home countries (Nordtveit, 2011, p. 106 f.). "Other Western countries are following the same pattern, and rather give scholarships to postgraduate students. This makes it possible for the donor country to consider the mature students; if they are very good, they can be kept in the host country. If they are arriving in the donor country when they are too young, they don't want to go back to Cameroon, whereas older people with a family are willing to go back" (ibid.).

This must not necessarily be the case; though a huge number of Cameroonians do stay in Germany, many of them return to Cameroon. The Centre for International Migration and Development (Müller, 2019) counted about 64 Cameroonian returnees between 2015 and 2018 (numbers of returnees who are supported by other agencies are however not included), who have resettled via the mobility programmes offered by the GIZ and the Center for International Migration and Development (CIM). All of them were noticed to be university graduates. Most of the interviewed German language students aspire to return to their home country, Cameroon, after their study stay in Germany. They attempt to gain necessary competencies and knowledge in Germany which they hope to later implement for Cameroon's development and technological advancement.

Hence, German foreign education policies appear to remain lip confessions which are not put into meaningful and effective practices in the case of Cameroon. In fact, the propaganda to 'expand university access in Germany' which was promulgated by the German Vice President of the house of representatives (German Bundestag), Ulla Schmidt, in the year 2006 has since then not yet been implemented here, as demanded: 
"Beyond mere language acquisition, continuous educational support is also a long-term concern of foreign cultural and educational policy. From German foreign and partner schools or study programs of the German Academic Exchange Services to alumni activities: At the end of the educational support are highly qualified people who are permanently connected to Germany by their educational biography. For this reason (...) we must also make greater efforts to expand university access in Germany. This is especially true in the context of rising immigration" (Schmidt, 2016, p. 2).

Currently, the PRC is actively sponsoring more than 70,000 African students with study visas at Chinese universities (Kappel, 2018, p. 3) and in so doing continuously puts into practice its cooperation plans with African countries, as stipulated in the FOCAC (Forum on China-Africa Cooperation) plans of actions which finally leads to intensified public diplomacy ties with the African societies. Thereby it attempts to heavily benefit from Chinese speaking Cameroonians they had previously invested in training for. Moreover, it can also be argued that the PRC practices forms of soft power or even hegemonic policy, as elder Chinese language students are issued scholarships and visas to continue their studies in China and can later serve as useful gatekeepers to the Cameroonian companies they had been previously working with. This finding can be corroborated with prior research, which also emphasises the current urgent need of Chinese companies in Cameroon for translators, interpreters etc. who are competent in speaking Chinese (Nordtveit, 2011). Discriminating by age would hence torpedo their business objectives of recruiting gatekeepers to the Cameroonian economy.

The results of the interview study presented here resonate with the fact that there is a great demand for Chinese speaking Cameroonians since the PRC 'has become Africa's largest trade partner' (IOSC, 2013). Especially now, as the PRC is implementing macro infrastructural projects involving vast parts of African regions e.g. as part of the new Silk-Belt Road projects (IOSC, 2015). China's Information Office of the State Council (IOSC, 2013) constitutes that in the year 2017 Cameroon's exports to China augmented to the sum of about 788 Million US Dollars, compared to app. 180 Million US Dollars in the year 2008 (ITC 2018). Although the PRC is a comparably new partner in development cooperation, Africa has received 3.4 billion US Dollars of development aid from the PRC in the years between 2000 and 2014 (Chandran, 2017). The PRC's foreign development aid, which has been part of the FOCAC agreements, is now officially institutionalized as China has recently installed its "International Development Cooperation Agency" which shifts the country's position from a recipient to a donor country (IOSC, 2018). In how far Sino-Cameroonian cooperation will continue to be a "win-winsituation" as it is at times referred to, needs to be evaluated in future, since the agency came into existence only in April 2018.

Compared to the economic involvement of the PRC in Cameroon, Germany's cooperation is of minor relevance (Statistisches Bundesamt, 2018), likewise its influence as a donor country, since development aid with Cameroon amounted to (only) 125,5 Million Euro (BMZ, 2018). The German-Cameroonian trade volume also stagnates on a low level of 43,680 Million Euro in the year 2017, which is only one fifth of the sum traded between China and Cameroon. The Afro-German development cooperation is anchored in the 2017 Marshall Plan for Africa, following its main objective to create new job perspectives, educational institutions and vocational training for young Africans and to establish structures enabling a prospective future for them (ibid., p. 5; 10), and in so doing, such a policy at least implicitly tries to minimize motives for their migration from their home countries. However, education and international mobility programmes between Cameroonian and German higher education institutions are not part of the package.

\section{Summary}

This contribution has aimed to examine in how far the foreign cultural and educational policies, which Cameroon shares with China and Germany, affect the international mobility of Cameroonian graduates. This has been demonstrated by means of an exploratory survey at the Goethe Institute and the Confucius Institute in Yaoundé.

The differences in motives for international mobility in higher education of the two compared samples of students reflect the strategies of foreign educational policies implemented by the PRC and Germany. Whereas the PRC attempts clear cut goals for economic investments and development cooperation, Germany does not provide such a specified strategy for either economic or cultural and educational cooperation with Cameroon. Also, the visa policies are opaque and the mechanisms for undergraduate higher education mobility to Germany are virtually non-existent.

Due to this lack of clarity, it was not possible, however, to exactly define, in how far the visa policy is related to German foreign cultural and educational policies or cooperation measures with Cameroon. Hence, it would be interesting to find correlating data which portray the strategies of education cooperation between Cameroon and Germany and to figure out the exact mechanisms of higher education mobility provided to Cameroonian students planning to study at a German university.

Also, long-term trends and experiences with the Chinese scholarship policies need to be observed as well as what becomes of the Cameroonian students studying in China after their return to Cameroon, or to another country, or how many of them will remain in China.

\section{References}

Adick, C. (2016). German foreign cultural and educational policy as a means of soft power. Hungarian Educational Research Journal, 6(3), 11-22. [https://doi. org/10.14413/herj.2016.03.02.]

Auswärtiges Amt (2015). Deutsch als Fremdsprache weltweit. Datenerhebung 2015. Access on 26.03.2019 https://www.auswaertiges-amt.de/blob/201002/b60a04e786 1a84b32bee9d84f7d38d86/publstatistik-data.pdf

Auswärtiges Amt (2018). Auswärtige Kultur-und Bildungspolitik. Kulturelle Angebote aus Deutschland schaffen weltweit Vertrauen in unser Land. Access on 26.03.2019 https://www.auswaertiges-amt.de/de/aussenpolitik/themen/kulturdialg/01-zieleund-aufgaben

Bundesministerium für wirtschaftliche Zusammenarbeit und Entwicklung (BMZ) (2018). Afrika südlich der Sahara. Kamerun. Access on 26.03.2019 http://www.bmz. de/de/laender_regionen/subsahara/kamerun/index.jsp

Burkhart, S., Chehab van den Assem, N., Grützmacher, J., Heublein, U., Kammüller, S., \& Kercher, J. (2016). Wissenschaft Weltoffen 2016. Daten und Fakten zur Internationalität von Studium und Forschung in Deutschland. Bielefeld: Bertelsmann. 
Chandran, N. (2017). 5 charts that show how China is spending billions in foreign aid. Access on 26.03.2019 https://www.cnbc.com/2017/10/13/china-development -aid-how-and-where-beijing-is-spending-its-cash.html

Centre for International Migration and Development (CIM). Email correspondence from 30.01.2019. Mimeo.

Confucius Institute Headquarters (Hanban) (2014). About us. Beijing. Access on 26.03.2019 http://english.hanban.org/node_7719.htm

Deutsche Botschaft Jaunde (2018). Visum zu Studienzwecken. Access on 26.03.2019 https://jaunde.diplo.de/cm-de/service/-/1602740

Forum on China-Africa Cooperation (FOCAC) (2006). Forum on China-Africa Cooperation. Beijing Action Plan (2007-2009). Access on 26.03.2019 https://www. fmprc.gov.cn/zftt/eng/ltda/dscbzjhy/DOC32009/t280369.htm

Information Office of the State Council (IOSC) (2013). China-Africa Economic and Trade Cooperation. Access on 26.03.2019 http://english.gov.cn/archive/white_ paper/2014/08/23/content_281474982986536.htm

Information Office of the State Council (IOSC) (2015). Action plan on the Belt and Road Initiative. Access on 26.03.2019 http://english.gov.cn/archive/publications/ 2015/03/30/content_281475080249035.htm

Information Office of the State Council (IOSC) (2018). China unveils international development cooperation agency. Access on 26.03 .2019 http://english.gov.cn/state_ council/ministries/2018/04/19/content_281476116927688.htm

International Trade Center (ITC) (2018). Trade map - trade competitiveness map2017. Bilateral trade between Cameroon and China in 2017. Product: TOTAL All products. Geneva. Access on 26.03.2019 https://www.trademap.org/countrymap/Bilateral.aspx?nvpm=1|120||156||TOTAL|||2|1|2|2|1|1|1|1|1\#RatePage

Kappel, R. (2018). China, Großbritannien und Deutschland in Afrika. Diskurs über die deutsche Afrikapolitik notwendig. Weltneuvermessung. Access on 26.03.2019 https://weltneuvermessung.wordpress.com/2018/09/03/china-grossbritannienund-deutschland-in-afrika-diskurs-ueber-die-deutsche-afrikapolitik-notwendig/

King, K. (2013). China's Aid and Soft Power in Africa: The Case of Education and Training. Rochester \& Suffolk: Boydell \& Brewer.

Müller, Gerd (2019): AW: AW: Quoten Rückkehrer Deutschland - Kamerun. E-Mail to Gerd.Mueller@zav-cimonline.de, 30.01.2019.
Nye, Joseph (1990): Soft power. Foreign Policy, 80, 153-171.

Nordtveit, B. H. (2011). An emerging donor in education and development: A case study of China in CameroonInternational. Journal of Educational Development, 31, 99-108. [https://doi.org/10.1016/j.ijedudev.2010.01.004]

Ndukong, K. H. (2017). Cameroon: Chinese Language - Confucius Institute to Train More Cameroonian Instructors. Embassy of the People's Republic of China in the Republic of South Africa. Access on 26.03.2019 http://za.china-embassy.org/eng/znjl/ t1495433.htm

Schmidt, U. (2016). Deutsch als Fremdsprache. PASCH - Schulen sind Partner der Zukunft. Access on 26.03.2019 https://www.kulturrat.de/themen/europainternationales/auswaertige-kultur-bildungspolitik-akbp/deutsch-als-fremdsprachel

Schneider, W., \& Kaitinnis, A. (2016). Auswärtige Kulturpolitik. Beiträge zu Theorie und Praxis binationaler Beziehungen. In W. Schneider, \& A. Kaitinnis (ed.) Kulturarbeit in Transformationsprozessen. Innenansichten zur ,Außenpolitik' des Goethe-Instituts. Wiesbaden: Springer Fachmedien, 9-17. [https://doi.org/10.1007/9783-658-13259-0_1]

Statistisches Bundesamt (2018). Rangfolge der Handelspartner im Außenhandel der Bundesrepublik Deutschland. Access on 26.03.2019 https://www.destatis.de/DE/ ZahlenFakten/GesamtwirtschaftUmwelt/Aussenhandel/Tabellen/Rangfolge Handelspartner.pdf?_blob=publicationFile

\section{Dr. Ina Gankam Tambo}

Doctoral degree at the Ruhr-University of Bochum (2014) with research on child domestic work in Nigeria. She is a lecturer at the Université Protestante d'Afrique Centrale in Yaoundé (Cameroon) and has taught at the Ruhr-University of Bochum. Her research focuses on socialisation and school theory, especially in the context of social inequality and in international and historical comparative perspectives. Recently (in 2019) Ina Gankam Tambo founded the German International School of Yaounde where she now acts as the school's directress. 